FITRAH Jurnal Kajian Ilmu-ilmu Keislaman

Vol. 04 No. 2 Desember 2018

e-ISSN : 2460-2345, p-ISSN: 2442-6997

Web: jurnal.iain-padangsidimpuan.ac.id/index.php/F

\title{
PUTUSAN MK NO. 46/2010 TENTANG HUBUNGAN KEPERDATAAN ANTARA ANAK LUAR NIKAH DENGAN AYAH BIOLOGIS (ANALISIS DALAM PERSPEKTIF HUKUM ISLAM, HUKUM POSITIF, UIDHR, Dan UDHR)
}

\author{
NUR AZIZAH \\ IAIN Manado Sulawesi Utara \\ nurazizahhutagalungdo@gmail.com
}

\begin{abstract}
The Constitutional Court is a legal institution where the judicial review of the law in Indonesia. In 2010, there was a judicial review of the article on marriage registration and the rights of children outside marriage or the marriage of Sirri. Although not all lawsuits were granted by the Constitutional Court judge, but the decision that was born raised its own polemic. The article of the Marriage Law of article 43 takes place in the provision of point content where an illegitimate child occupies a state-recognized status with proof of technology. Therefore, the interpretation of UDHR, UIDHR, Islamic Law, Positive Law, and Child Protection Law and MUI's Fatwa on the decision strongly contributed in interpreting the Constitutional Court's decision and the word "civil relationship" with biological father.
\end{abstract}

Keywords: out of wedlock children, Constitutional Court, Marriage Law, and Islamic Law.

\begin{abstract}
Abstrak
Mahkamah Konstitusi adalah lembaga hukum tempat judicial review hukum di Indonesia. Pada tahun 2010, ada peninjauan kembali artikel tentang pendaftaran pernikahan dan hak-hak anak di luar nikah atau pernikahan Sirri. Meskipun tidak semua tuntutan hukum diberikan oleh hakim Mahkamah Konstitusi, tetapi keputusan yang lahir mengangkat polemiknya sendiri. Pasal Hukum Perkawinan pasal 43 terjadi dalam penyediaan isi poin di mana seorang anak tidak sah menempati status yang diakui negara dengan bukti teknologi. Oleh karena itu, interpretasi UDHR, UIDHR, Hukum Islam, Hukum Positif, dan UU Perlindungan Anak dan Fatwa MUI pada keputusan sangat berkontribusi dalam menafsirkan keputusan Mahkamah Konstitusi dan kata "hubungan sipil" dengan ayah biologis.
\end{abstract}

Kata kunci: anak luar nikah, mahkamah konstitusi, hukum pernikahan, dan hukum Islam.

\section{PENDAHULUAN}

Pada dasarnya tujuan hukum adalah demi menjaga ketertiban dan kedamaian serta menjamin hak-hak setiap warga negara atau setiap orang. 
FITRAH Jurnal Kajian Ilmu-ilmu Keislaman

Vol. 04 No. 2 Desember 2018

Seiring berkembangnya zaman, kebutuhan akan hukum semakin meningkat, maka secara otomatis hukum yang kaku harus dapat dilakukan pembaruan. Namun pembaruan hukum yang dimaksud tidak sampai merusak sendi-sendi aturan dasar.

Sejak zaman sebelumnya hingga tahun 2010 masih dipegang sebuah aturan yang ketat tentang anak luar nikah. Bahwa anak hasil zina atau hasil hubungan luar nikah dipandang sebagai makluk yang tidak memiliki hubungan keperdataan apapun dengan ayah biologisnya. Hingga kemudian tejradi pengajuan uji materi hukum tentang pencatatan nikah dan hak anak atas UU No. 1 Tahun 1974 pada Mahkamah Konstitusi.

Pembaruan hukum yang lahir dari putusan MK melahirkan sebuah polemik hingga secara cekatan Majelis Ulama Indonesia mengeluarkan keputusan dengan judul Fatwa MUI No. 11 Tahun 2012. Tidak sampai di situ saja, gejolak pro dan kontra tentang putusan MK menimbulkan dilema dalam penafsiran hukum.

Maka, berdasarkan permasalahan tersebut penulis akan memabahas bagaimana sebanarnya hukum Islam, Hukum Positif, Universal Declaration of Human Right (UDHR) tentang HAM dalam PBB, Universal Islamic Declaration of Human Right (UIDHR) tentang HAM dalam Islam, dan UU No. 23 Tahun 2002 tentang perlindungan anak. Keseluruhan akan memberikan sudut pandang maasing-masing terhadap putusan Mahkamah Konstitusi.

\section{METODE PENELITIAN}

Penelitian ini menggunakan metode kualitatif dengan pendekatan normatif. Sumber data primer dari penelitian ini adalahPutusan MK No.46/2010 tentang hubungan keperdataan antara anak di luar nikah dengan ayah biologis, hokum Islam, hukum positif, UIDHR dan UDHAR. Data sekunder diperoleh dari teori-teori dan konsep yang terkait dengan pokok persoalan tersebut di atas. Teknik pengumpulan data melalui ribrary riset dan telaah pustaka. Untuk analisa data dengan menganalisa, mengkolaborasikan Putusan MK No.46/2010, hukum Islam, hukum positif, UIDHR dan UDHR dan selanjutnya diambil kesimpulan. 


\section{HASIL KAJIAN TEORITIS DAN PEMBAHASAN}

\section{Penjelasan tentang Putusan}

Isi putusan menunjukkan bahwa antara ayah biologis dengan anak memiliki hubungan keperdataan secara hukum negara, ini artinya antara anak dan ayah (keluarga ayah) memiliki hubungan keperdataan dalam arti berhak saling mewarisi, menyandang nama ayah, dan hubungan hukum lainnya selayaknya keluarga kecuali dalam hal nasab, sebab nasab adalah ranah agama, agamalah yang menentukan seseorang tersebut memiliki nasab atau tidaknya dengan ayah.

Dalam putusan MK menunjukkan pernikahan sirri tidak dapat disahkan dan anak yang lahir atas pernikahan di bawah tangan (sirri) tidak serta merta mendapatkan hak dan statusnya setelah adanya putusan MK, harus terlebih dahulu dibuktikan dengan alat teknologi atau bukti lainnya yang menandakan adanya hubungan darah. Sementara ibu dari anak hasil pernikahan di bawah tangan tidak memiliki hubungan apapun dengan suaminya dari pernikahan sirri tersebut.

Anak luar nikah yang dimaksud MK adalah anak hasil pernikahan sirri (tidak dicatatkan) dan anak-anak yang lahir akibat hubungan seksual antara lakilaki dan wanita. Atas putusan inilah, banyak pihak dan masyarakat berpikir bahwa akibat putusan ini dapat mempersamakan antara anak hasil pernikahan sirri dengan zina. Putusan ini dikhawatirkan berimplikasi pada pelegalan zina.

Maka dari itu, MK memberikan penjelasan secara resmi pada hari rabu 7 Mret 2012 bahwa MK tidak melegislasi perzinaan. MK menerangkan:“Seoranglaki-laki dan seorang perempuan yang menyebabkan terjadinya kelahiran anak tersebut harus bertanggungjawab atas kelangsungan hidup, tumbuh, dan berkembang serta berhak atas perlindungan dari kekerasan dan diskriminasi".

Sisi tanggung jawab kedua orang tuanya dan aspek kepentingan anaklah yang sangat ditekankan, bukan dimaksudklan untuk melegalkan perzinaan.

Selain mendengar keterangan ahli, majelis hakim Mahkamah Konstitusi juga mendengarkan berbagai masukan dari pihak pemerintah, pihak DPR. Pihak pemerintah menyampaikan paparan dan alasan panjang yang kesimpulannya adalah bahwa berdasarkan penjelasannya tersebut di atas, pemerintah memohon kepada MK yang mengadili permohonan penguji UU No. 1 Tahun 1974 tentang perkawinan terhadap UU 1945, dapat memberikan putusan sebagai berikut: 
FITRAH Jurnal Kajian Ilmu-ilmu Keislaman

Vol. 04 No. 2 Desember 2018

pertama, pemohon tidak mempunyai kedudukan hukum (legal standing); kedua, menolak permohonan penguji para pemohon seluruhnya atau setidak-tidaknya menyatakan permohonan penguji para pemohon tidak dapat diterima; ketiga, menerima keterangan pemerintah secara keseluruhan,; keempat, menyatakan ketentuan pasal 2 ayat (2) dan pasal 43 ayat (1) UU Perkawinan 24 tidak bertentangan dengan pasal 28B ayat (1) dan ayat (2) serta pasal 28 (D) ayat (1) UUD 1945; namun demikian apabila MK berpendapat lain, mohon putusan yang bijaksana dan seadil-adilnya. ${ }^{1}$

Hak dan Kewajiban, Hubungan dan Perlindungan Hukum dalam pandangan Hukum Islam, Hukum Positif, dan UIDHR, dan UDHR

Sebagaimana penjelasan putusan di atas, hak dan kewajiban para pihak setelah putusan MK adalah anak memiliki hak keperdataan kepada ayah biologis. Artinya ayah biologis harus memberikan hak-hak anak selayaknya dan melaksanakan kewajiban sebagaimana seorang ayah. Akan tetapi laki-laki tersebut tidak memiliki hubungan suami istri dengan wanita pemilik anak terkecuali dengan pernikahan yang sah secara hukum di Indonesia.

Putusan Mahkamah Konstitusi tidak mengakibatkan wanita dan laki-laki yang mengakibatkan kelahiran anak memiliki hubungan suami istri. Putusan ini hanya menegaskan hubungan antara orangtua dengan anak biologis. MK tidak memberikan keterangan secara jelas apakah hubungan perdata ini sampai kepada hubungan nasab atau hanya sebatas hak-hak perdata lainnya. Kata hubungan perdata ini sudah sepatutnya diberikan tafsiran secara jelas oleh MK agar tidak terjadi kekosongan hukum supaya pasal ini tidak dimanfaatkan oleh suatu oknum untuk mempermaikan hukum.

\section{Hak dan Kewajiban, Hubungan dan Perlindungan Hukum dalam isi putusan MK ditinjau dari Hukum Islam}

Yang dimaksud dengan anak zina ialah anak yang dilahirkan bukan karena hubungan perkawinan yang sah. Anak zina tidak dianggap sebagai anak dari laki-laki yang menggauli ibunya, walaupun laki-laki tersebut kelak ولد menikahi ibunya. Anak yang lahir disebabkan hubungan tanpa nikah disebut walad gairu syar'i (anak tidak sah).

${ }^{1}$ H. M. Nurul Irfan, Nasab E status anak dalam hukum Islam (Jakarta: AMZAH, 2013), hlm. 185. 
Oleh karena itu, tidak ada hubungan nasab/keturunan dengan laki-laki itu, namun anak itu tetap mempunyai hubungan nasab dengan ibunya dan kerabat ibunya.

Imam Syafi'i menyatakan bahwa jika seorang wanita hamil karena zina melahirkan anaknya,baik orang yang melakukan zina mengaku atau tidak mengaku, maka anak yang lahir tersebut adalah anak dari ibunya, bukan dari anak laki-laki yang menzinainya. ${ }^{2}$

Tujuan adanya syari'at adalah untuk mencapai kemaslahatan. Beberapa kemaslahatan pokok adalah: menjaga agama, jiwa, akal, harta dan keturunan. Demi menjaga nasab atau keturunan inilah ajaran agam Islam mensyari'atkan nikah sebagai cara yang dipandang sah untuk menjaga dan memelihara kemurnian nasab.

Dengan demikian nasab adalah sebuah karunia besar yang diturunkan Allah kepada hamba-Nya, sesuai dengan firman Allah:

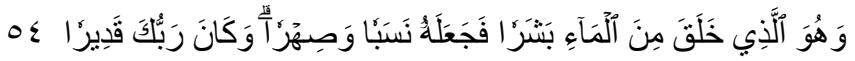

54. Dan Dia (pula) yang menciptakan manusia dari air lalu dia jadikan manusia itu (punya) keturunan dan mushaharah dan adalah Tuhanmu Maha Kuasa.

Dalam kaitan ini pula seorang ayah dilarang mengingkari keturunannya dan haram pula bagi seorang wanita menisbahkan (menghubungkan) seorang anak kepada yang bukan ayah kandungnya, seperti dalam hadis Rasulullah bersabda: ${ }^{3}$

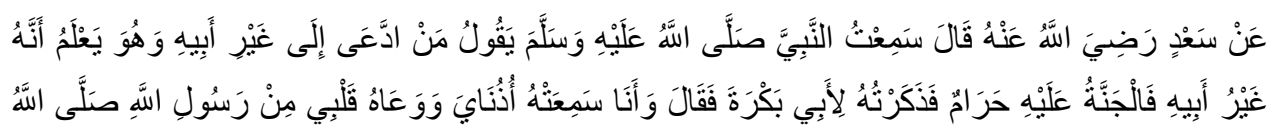

$$
\text { عَلَيْهِ وَستََّّ }
$$

Dari Abu Utsman dari Sa'd radliallahu 'anhu mengatakan, aku menengar Nabi Shallallahu'alaihiwasallam bersabda; "Barangsiapa menasabkan diri kepada selain ayahnya padahal ia tahu bukan ayahnya maka surga haram baginya." Maka aku sampaikan hadits ini kepada Abu Bakrah dan ia berkata; 'Aku mendengarnya dengan kedua telingaku ini dan hatiku juga mencermati betul dari Rasulullah Shallallahu'alaihiwasallam! (HR. Bukhari No. 6269).

Jumhur ulama telah sepakat bahwa anak-anak hasil zina tidak digolongkan ke dalam nasab bapak-bapak mereka kecuali (hal itu terjadi) pada masa Jahiliyah berdasarkan hadis yang diriwayatkan dari Umar bin Khattab ra

\footnotetext{
${ }^{2}$ Amin Husein Nasution, Hukum Kewarisan (Jakarta: Rajawali Pers, 2012), hlm. 189-190.

${ }^{3}$ Nasution, Hukum Kewarisan..., hlm. 6-9.
} 
FITRAH Jurnal Kajian Ilmu-ilmu Keislaman

Vol. 04 No. 2 Desember 2018

bersamaan dengan adanya perbedaan di kalangan para sahabat sendiri. Segolongan ulama memiliki pendapat syadz, mereka berpendapat bahwa anak zina pun digolongkan (ke dalam nasab bapaknya) pada jaman Islam, artinya digolongkan ke dalam nasab orang yang berzina pada masa Islam. ${ }^{4}$

Berbeda dengan pendapat jumhur ulama, Ibnu Taimiyah tetap mengakui adanya hubungan nasab antara anak zina dengan ayahnya, alasannya sanksi zina ditimpakan kepada pelaku perbuatan zina baik di dunia maupun di akhirat, bukan kepada anak yang dilahirkan.

Pada masa sahabat dan ulama mazhab dikenal ahli nasab yang dapat menetapkan tentang nasab seorang anak. Yaitu dua orang yang melakukan persetubuhan dalam satu masa suci, baik karena sebab perbudakan atau pernikahan, artinya perzinaan tidak termasuk pada kategori ini. Para ulama yang berpegang pada putusan ini adalah Imam Malik, Syafi'i, Ahmad, Abu Tsaur, dan Al-Auza'i.

Para Ulama Kufah dan mayoritas ulama Irak menolak qafah, harus ada pengakuan. Apabila diakui oleh dua orang, maka anak tersebut milik keduanya asalkan hubungan tersebut bukan atas dasar perzinaan. Dasar pijakan mereka menganut putusan qafah adalah sebuah hadis yang diriwayatkan oleh Malik dari Sulaiman bin Yasar: Bahwa Umar bin Khattab memberikan putusan atas anakanak yang terlahir pada masa Jahiliyah untuk bercampur dengan orang-orang tua mereka, yaitu mereka yang mengakuinya dalam masa Islam. ${ }^{5}$

Anak-anak yang lahir akibat hubungan antara pria dan wanita di masa jahiliyah belum termasuk kepada pelanggaran hukum karena Islam hadir setelahnya sehingga anak-anak tersebut dinasabkan kepada bapak-bapak mereka.

Jadi, dalam hal nasab, kedudukan anak Machicha Mochtar mantan istri sirri Moerdiono (dalam putusan MK) yang menjadikan statusnya menjadi anak di luar nikah bertentangan dengan hukum Islam. Sebab secara syara' mereka telah menikah secara syariat namun tidak dicatatkan. Dalam hal ini anak yang lahir akibat pernikahan sirri tidak dapat dipersamakan statusnya dengan anak luar nikah lainnya (hasil zina).

\footnotetext{
${ }^{4}$ Ibnu Rusyd, Bidayatul Mujtahid (Jakarta: Pustaka Azzam, 2007), hlm 717.

${ }^{5}$ Rusyd, Bidayatul Mujtahid..., 719-20.
} 
Secara garis besar, kewarisan dilakukan karena beberapa sebab yaitu hubungan kekerabatan nasab, hubungan pernikahan yang sah, dan hubungan kekerabatan hukmiyah (pembebasan budak). ${ }^{6}$

Allah berfirman:

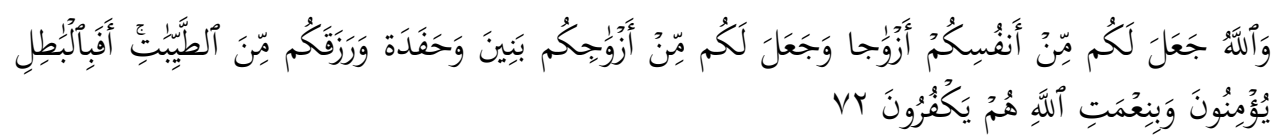

72. Allah menjadikan bagi kamu isteri-isteri dari jenis kamu sendiri dan menjadikan bagimu dari isteri-isteri kamu itu, anak-anak dan cucu-cucu, dan memberimu rezeki dari yang baik-baik. Maka mengapakah mereka beriman kepada yang bathil dan mengingkari nikmat Allah? (Qs. An-Nahl ayat 72).

Dapat disimpulkan berdasarkan pendapat yang kuat yaitu, jumhur ulama. anak hasil zina tidak dapat dinasabkan sama sekali kepada bapaknya sekalipun telah ada pengakuan atau jenis bukti lainnya. Beda halnya dengan anak zina (luar nikah), anak hasil perkawinan sirri (tanpa pencatatan), maka terdapat hubungan nasah secara langsung kepada si bapak.

Dalam hal nafkah, secara otomatis, anak hasil pernikahan sirri yang telah diakui hubungan nasabnya maka secara otomatis si bapak berkewajiban memberikan nafkah sebagai mana anak-anak kandung lainnya yang ditetapkan syariat. Sedangkan anak hasil zina yang dapat dibuktikan secara pengetahuan teknologi terdapat hubungan darah dengan seorang laki-laki,maka putusan MK bersesuai dengan hukum Islam dalam hal pemberian belanja dan nafkah anak.

Allah berfirman:

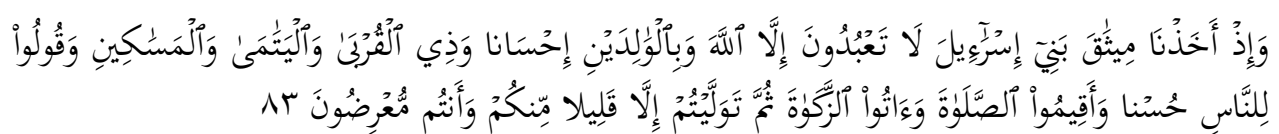

83. Dan (ingatlah), ketika Kami mengambil janji dari Bani Israil (yaitu): Janganlah kamu menyembah selain Allah, dan berbuat kebaikanlah kepada ibu bapa, kaum kerabat, anak-anak yatim, dan orang-orang miskin, serta ucapkanlah kata-kata yang baik kepada manusia, dirikanlah shalat dan tunaikanlah zakat. Kemudian kamu tidak memenuhi janji itu, kecuali sebahagian kecil daripada kamu, dan kamu selalu berpaling

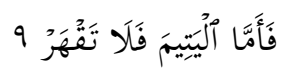

"Sulhani Hermawan, "Kedudukan Waris Anak di Luar Nikah" dalam Problematika Hukum Kewarisan Islam Kontemporer di Indonesia, diedit oleh Muchit A.Karim (Jakarta: Puslitbang Kehidupan Keagamaan Badan Litbang dan Diklat Kementerian Agama RI, 2012), hlm. 289, http://simbi.kemenag.go.id/pustaka/images/materibuku/problematika\%20hukum\%20kewarisan\%2 0islam\%20kontemporer\%20di\%20indonesia-2012.pdf. 
FITRAH Jurnal Kajian Ilmu-ilmu Keislaman

Vol. 04 No. 2 Desember 2018

9. Sebab itu, terhadap anak yatim janganlah kamu berlaku sewenang-wenang.

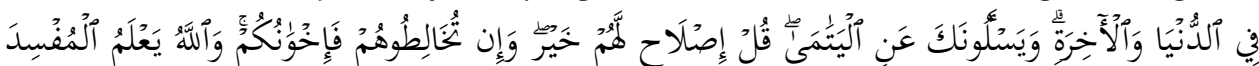

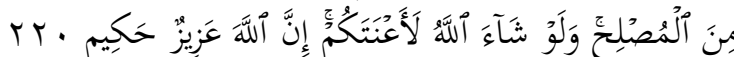

220. tentang dunia dan akhirat. Dan mereka bertanya kepadamu tentang anak yatim, katakalah: "Mengurus urusan mereka secara patut adalah baik, dan jika kamu bergaul dengan mereka, maka mereka adalah saudaramu; dan Allah mengetahui siapa yang membuat kerusakan dari yang mengadakan perbaikan. Dan jikalau Allah menghendaki, niscaya Dia dapat mendatangkan kesulitan kepadamu. Sesungguhnya Allah Maha Perkasa lagi Maha Bijaksana. (AlBaqarah ayat 210).

Anak yang lahir pada dasarnya adalah suci dan tidak mengemban dosa kedua orang tua. Bahkan untuk anak yatim yang tidak memiliki hubungan apapun dengan manusia lainnya diwajibkan untuk diperlakukan dengan baik dan disantuni. Sejak awal kita mengenal sedekah dan berbagi rezeki. Terlebih lagi kepada anak yang merupakan darah daging seorang laki-laki, sebab perbuatan laki-laki dan perempuan itulah ia terlahir. Maka sudah sepatutnya mempertanggungjawabkan anak tersebut dalam hal perbelanjaan (nafkah).

Isi putusan MK menunjukkan bahwa perempuan maupun laki-laki yang mengakibatkan lahirnya seorang anak, keduanya bertanggungjawab terhadap anak tersebut. Tawaran solusi terhadap polemik putusan MK tentang status anak luar kawin disampaikan dalam Fatwa MUI tentang status anak hasil zina dan perlakuan terhadapnya.

Harus diakui bahwa fatwa MUI tentang kedudukan anak hasil zina dan perlakuan terhadapnya ini muncul sebagai akibat atau respons atas putusan MK tentang status anak luar nikah yang merupakan bentuk dikabulkannya permohonan seorang mantan istri siri seorang pejabat kelas atas era Orde Baru.

Dalam fatwa MUI No. 11 Tahun 2012 tentang kedudukan anak hasil zina dan perlakuan terhadapnya, memutuskan: Ketentuan Hukum:

a. Anak hasil zina tidak mempunyai hubungan nasab, wali nikah, waris, dan nafaqah dengan lelaki menyebabkan kelahirannya.

b. Anak hasil zina hanya mempunyai hubungan nasab, waris, dan nafaqah dengan ibunya dan keluarga ibunya.

c. Anak hasil zina tidak menanggung dosa perzinaan yang dilakukan oleh orang yang mengakibatkan kelahirnannya

d. Pezina dikenakan hukuman Hadd oleh pihak yang berwenang untuk menjaga keturunan yang sah 
e. Pemerintah berwenang menjatuhkan hukuman takzir lelaki pezina yang mengakibatkan lahirnya anak dengan mewajibkan untuk:

1. Mencukupi kebutuhan hidup anak tersebut

2. Memberikan harta setelah ia meninggal melalui wasiat wajibah

Hukuman sebagaimana dimaksud nomor 5 bertujuan melindungi anak, bukan untuk mansahkan hubungan nasab antara anak tersebut dengan lelaki yang mengakibatkan kelahirannya. ${ }^{7}$

\section{Hak dan Kewajiban, Hubungan dan Perlindungan Hukum dalam isi putusan MK ditinjau dari UDHR}

Universal Declaration of Human Right (UDHR) diterima dan diumumkan oleh Majelis Umum PBB pada tanggal 10 Desember 1948 melalui resolusi 217 A (III). UDHR terdiri dari pasal-pasal penegakan hak asasi manusia di dunia menjamin hak setiap warga negara sebagai manusia. Apabila dihubungkan dengan hak-hak yang diperoleh anak luar nikah sebagaimna dalam putusan, maka ditemukan pasal-pasal yan terkait: Pasal 43 UU No. 1 Tahun 1974 pra putusan MK menyebutkan bahwa anak di luar nikah hanya memiliki hubungan nasab dengan ibu saja. Pasal ini dipandang kurang menjamin hak-hak setiap anak yang lahir. Karena pada dasarnya yang seharusnya bertanggungjawab terhadap anak yang lahir bukanlah pihak perempuan saja tetapi juga laki-laki.

Universal Declaration of Human Right menyebutkan bahwa setiap orang pada dasarnya lahir dengan memiliki hak dan martabat yang sama, meskipun itu anak hasil perkawinan sah maupun hubungan luar nikah. ${ }^{8}$ Sehingga keputusan MK dalam hal hubungan perdata terhadap ayah dan ibu biologis bersesuaian dengan harapan pasal 2 dan 10 UDHR.

Pasal 2

Setiap orang berhak atas semua hak dan kebebasan-kebebasan yang tercantum di dalam pernyataan ini tanpa perkecualian apapun, seperti ras, warna kulit, jenis kelamin, bahasa, agama, politik atau pendapat yang berlainan, asal mula kebangsaan atau kemasyarakatan, hak milik, kelahiran ataupun kedudukan lain.

${ }^{7}$ Irfan, Nasab E status anak dalam hukum Islam..., hlm. 234-237.

8 Majelis Umum PBB/ United Nations Information Centre, Indonesia, "Universal Declaration of Human Right (UDHR) tentang HAM Internasional," Web. Blog, 10 Desember 1948, https://www.ohchr.org/en/udhr/pages/Language.aspx?LangID=inz. 
FITRAH Jurnal Kajian Ilmu-ilmu Keislaman

Vol. 04 No. 2 Desember 2018

Di samping itu, tidak diperbolehkan melakukan perbedaan atas dasar kedudukan politik, hukum atau kedudukan internasional dari negara atau daerah dari mana seseorang berasal, baik dari negara yang merdeka, yang berbentuk wilayah-wilayah perwalian, jajahan atau yang berada di bawah batasan kedaulatan yang lain.

Pasal 10

Setiap orang, dalam persamaan yang penuh, berhak atas pengadilan yang adil dan terbuka oleh pengadilan yang bebas dan tidak memihak, dalam menetapkan hak dan kewajiban-kewajibannya serta dalam setiap tuntutan pidana yang dijatuhkan kepadanya.

Pasal 22

Setiap orang, sebagai anggota masyarakat, berhak atas jaminan sosial dan berhak akan terlaksananya hak-hak ekonomi, sosial dan budaya yang sangat diperlukan untuk martabat dan pertumbuhan bebas pribadinya, melalui usaha-usaha nasional maupun kerjasama internasional, dan sesuai dengan pengaturan serta sumber daya setiap negara.

\section{Hak dan Kewajiban, Hubungan dan Perlindungan Hukum dalam isi putusan MK ditinjau dari UIDHR}

Aspek-aspek hukum keluarga yang disoroti Universal Islamic Declaration of Human Right (UIDHR) juga tidak seluruhnya. Aspek-aspek itu adalah:

Tentang waris misalnya, dalam masalah waris ini UIDHR tidak menyebutnya secara panjang lebar/detail siapa saja yang dapat mewarisi harta ayah atau ibu yang meninggal (siapa yang menjadi ahli waris) dan berapa bagian masing-masing, siapa yang menjadi ahli waris ashabah, Aul, Radd dan konsepkonsep waris lainnya seperti yang ada didalam kitab-kitab fikih. UIDHR hanya menyatakan bahwa; istri mempunyai hak waris terhadap suaminya yang meninggal, terhadap ayahnya, anaknya dan keluarga-keluarga lainnya sesuai dengan hukum (Pasal XX ayat 4$).{ }^{9}$

Selanjutnya adalah masalah hadhanah, bahwa anak memiliki hak-hak atas ayahnya, hak yang dimaksud secara umum berupa nafkah juga pendidikan. Pasal-pasal UIDHR menjelaskan bahwa seorang ayah wajib memberi nafkah

${ }^{9}$ Muhammad Faisal Hamdan, Hukum Keluarga Islam dalam Perspektif HAM Universal (UDHR) dan HAM Islam (UIDHR) (Medan: Pasca Sarjana UIN Sumatera Utara, 2015), hlm. 27. 
pada istri dan anaknya sesuai dengan kemampuannya (Pasal XIX ayat 3). Dilihat dari pasal ini bahwa anak berhak untuk diberi nafkah oleh ayahnya bukan ibunya. Namun, jika orang tuanya (parents=baik bapak atau ibu, pen) tidak mampu memberi nafkah karena keadaan tertentu (misalnya karena miskin), maka hak nafkah anak ditanggung oleh negara (misalnya anak dapat ditampung di Panti Asuhan, Indonesia). Disamping itu, anak berhak mendapatkan dukungan materi (benda-benda materi lainnya), perhatian dan perlindungan dari orang tuanya semasa kecilnya atau ketika masa dewasa tetapi anak masih belum mempunyai rusd (kecerdasan yang menjadi kapasitas untuk berbuat) (Pasal XIX ayat [6]). Anak juga tidak boleh dipaksa bekerja pada usia yang relatif sangat muda atau walaupun berumur tetapi ia tidak mampu ditakutkan akan membahayakan pertumbuhan mereka (ayat [4]). Anak juga berhak mendapatkan pendidikan sesuai dengan kemampuannya (Pasal XIX ayat [1]) dan bahkan menuntut ilmu ini adalah kewajiban setiap orang Islam (Pasal XII ayat [2]). ${ }^{10}$

Dari pemaparan UIDHR di atas dapat ditarik benang merah bahwa sebenarnya hak waris anak terhadap orang tua tidak disebutkan dengan jelas. artinya, kedudukan anak luar nikah (hasil zina) masih memungkinkan sebagai ahli waris, tetapi juga bisa berarti tidak memperoleh harta waris. HAM Islam hanya memaparkan lebih rinci tentang hak waris seorang ibu atau istri.

Namun dalam hal nafkah dan pendidikan, pasal UIDHR nampaknya tidak membedakan antara anak luar nikah dan anak sah. Karena setiap anak memiliki hak dari orang taunya seperti belanja dan jaminan pendidikan sesuai kemampuan orang tua serta perlindungan dari orang tuanya.

\section{Hak dan Kewajiban, Hubungan dan Perlindungan Hukum dalam isi putusan MK ditinjau dari Hukum Positif di Indonesia \\ Kompilasi Hukum Islam dan UU No.1 Tahun 1974 tentang Perkawinan}

Defenisi anak yang sah dalam perspektif KHI diatur di dalam Bab XIV tentang pemeliharaan anak. Pasal 99 KHI mengatur bahwa anak yang sah menurut hukum adalah anak yang dilahirkan dalam atau akibat perkawinan yang sah. Termasuk dihitung sebagai anak yang sah ketika pembuahan dilakukan oleh suami istri yang sah di luar rahim dan dilahirkan oleh suami istri tersebut.

\footnotetext{
${ }^{10}$ Hamdan, Hukum Keluarga Islam dalam Perspektif HAM Universal ..., hlm. 27.
} 
FITRAH Jurnal Kajian Ilmu-ilmu Keislaman

Vol. 04 No. 2 Desember 2018

Anak yang tidak sah atau anak di luar nikah adalah anak yang lahir di luar atau bukan akibat perkawinan yang sah. Pasal $100 \mathrm{KHI}$ mengatur bahwa anak yang lahir di luar perkawinan hanya mempunyai hubungan nasab dengan ibunya dan keluarga ibunya.

Akhmad Junaedi menegaskan bahwa menurut Burgelijk Wetboek (BW), anak di luar perkawinan adalah anak yang dibenihkan dan dilahirkan di luar perkawinan sah dan tidak termasuk anak zina dan anak sumbang. Menurut sistem yang dianut BW pasal 272 "adanya keturunan di luar perkawinan saja belum terjadi suatu hubungan nasab antara anak dengan orang tuanya, baik dengan bapak maupun ibunya".

Berdasarkan pasal 280 BW dengan adanya pengakuan, anak diluar perkawinan memiliki hubungan perdata dengan ayah biologis termasuk dalam hal waris. Pasal 103 KHI menjelaskan bahwa anak yang lahir akibat perkawinan di bawah tangan (tidak dicatatkan) dianggap sebagai anak tidak sah. ${ }^{11}$ Secara otomatis tidak ada keterikatan hubungan antara suami istri yang menikah sirri. Mungkin inilah alasan MK memutuskan permohonan Machicha Muchtar dengan menyebutkan anak hasil perkawinan sirri dengan Moerdiono sebagai "anak di luar nikah".

Dalam pasal 2 UU No. 11974 disebutkan:

\section{Pasal 2}

1) Perkawinan adalah sah, apabila dilakukan menurut hukum masingmasing agamanya dan kepercayaannya itu.

2) Tiap-tiap perkawinan dicatat menurut peraturan perundang-undangan yang berlaku.

Hukum agama Islam di Indonesia tentang perkawinan yang berkekuatan tetap dan pasti adalah KHI dan UU No. 1 Tahun 1974, sedangkan pernikahan menurut kepercayaan yaitu Islam hanya dengan syarat dan rukun saja sebelum dilakukan pembaruan.

Setelah putusan MK, pasal 43 ayat 1 UUP terdapat penambahan yakni : Anak yang lahir di luar perkawinan mempunyai hubungan perdata dengan ibu, keluarga ibu, dan laki-laki yang dapat dibuktikan dengan ilmu pengetahuan teknologi dan alat bukti lainnya sebagai ayah.

${ }^{11}$ Hermawan, "Kedudukan Waris Anak di Luar Nikah" dalam..., hlm. 294-297. 
Historisitas atau latar belakang adanya putusan ini adalah berkenaan dengan tuntutan atas hak-hak anak dari pernikahan yang tidak dicatatkan hingga berimplikasi pada lahirnya jaminan hukum terhadap hak-hak seluruh anak yang dikategorikan "anak luar nikah". Dapat diartikan bahwa dalam pandangan hukum positif, anak hasil perkawinan sirri adalah anak luar nikah.

Beberapa negara secara jelas mengatur tentang status atau posisi dari pencatatan tersebut, apakah pencatatan merupakan syarat kesahan secara agama. Di Indonesia aturan pencatatan perkawinan dapat dilihat di UU No. 22/1964. UU ini mengatur hanya administrasi perkawinan dan menegaskan bahwa perkawinan diawasi oleh pegawai pencatat nikah. Aturan pencatatan nikah diperkuat dalam UU No. 1 Tahun 1974 dan KHI. ${ }^{12}$ KHI dan UndangUndang Perkawinan menyatakan bahwa perkawinan dinyatakan sah apabila dilakukan menurut ajaran agama dan keyakinan masing-masing, dalam KHI dinyatakan apabila sesuai dengan ajaran Islam. Pencatatan perkawinan adalah sebuah kewajiban yang apabila dilanggar maka perkawinan tidak memiliki kekuatan hukum. Maka, faktor utama sahnya perkawinan adalah prosedur perkawinan yang sesuai dengan syariat bagi umat yang beragama Islam. Pencatatan perkawinan sekedar syarat administratif yang harus dipenuhi bagi setiap warga negara yang hendak menikah.

Maka, melihat penggunaan kata "anak luar nikah" secara umum dalam putusan MK tidak bertepatan dengan penafsiran hukum yang sebenarnya. Bahwa anak machicha muhtar yakni hasil perkawinan di bawah tangan atau tidak dicatatan tidak dapat dikategorikan sebagai anak luar nikah. Karena perkawinan telah dilakukan sebagaimana ajaran Islam hanya saja tidak mengikuti syarat administratif. Sedangkan anak yang lahir bukan dalam pernikahan, maka termasuk kepada anak luar nikah, yaitu anak hasil zina atau hubungan luar nikah lainnya.

\section{UU No. 23 Tahun 2002 tentang Perlindungan Anak tentang Hak dan Kewajiban}

\section{Pasal 4}

Setiap anak berhak untuk dapat hidup, tumbuh, berkembang, dan berpartisipasi secara wajar sesuai dengan harkat dan martabat kemanusiaan, serta mendapat perlindungan dari kekerasan dan diskriminasi.

\footnotetext{
${ }^{12}$ Asep Saepudin Jahar dan dkk, Hukum Keluarga, Pidana, dan Bisnis (Jakarta: Kencana Prenadamedia Group, 2013), hlm. 26.
} 
FITRAH Jurnal Kajian Ilmu-ilmu Keislaman

Vol. 04 No. 2 Desember 2018

\section{Pasal 5}

Setiap anak berhak atas suatu nama sebagai identitas diri dan status kewarganegaraan.

\section{Pasal 6}

Setiap anak berhak untuk beribadah menurut agamanya, berpikir, dan berekspresi sesuai dengan tingkat kecerdasan dan usianya, dalam bimbingan orang tua.

\section{Pasal 7}

1) Setiap anak berhak untuk mengetahui orang tuanya, dibesarkan, dan diasuh oleh orang tuanya sendiri.

2) Dalam hal karena suatu sebab orang tuanya tidak dapat menjamin tumbuh kembang anak, atau anak dalam keadaan terlantar maka anak tersebut berhak diasuh atau diangkat sebagai anak asuh atau anak angkat oleh orang lain sesuai dengan ketentuan peraturan perundangundangan yang berlaku.

\section{Pasal 8}

Setiap anak berhak memperoleh pelayanan kesehatan dan jaminan sosial sesuai dengan kebutuhan fisik, mental, spiritual, dan sosial.

\section{Pasal 9}

1) Setiap anak berhak memperoleh pendidikan dan pengajaran dalam rangka pengembangan pribadinya dan tingkat kecerdasannya sesuai dengan minat dan bakatnya.

2) Selain hak anak sebagaimana dimaksud dalam ayat (1), khusus bagi anak yang menyandang cacat juga berhak memperoleh pendidikan luar biasa, sedangkan bagi anak yang memiliki keunggulan juga berhak mendapatkan pendidikan khusus.

Dari setiap pasal perlindungan anak di atas terdapat kesamaan dengan putusan MK yang juga mempertimbangkan pasal 4 dalam mengabulkan satu permohonan pemohon. Dilihat juga dari setiap pasal, nampaknya MK berupaya mengabulkan apa yang sudah menjadi hak setiap anak dalam UU no. 23 Tahun 2002. 


\section{Polemik Antara Hukum Islam dan Hukum Positif tentang Hubungan Perdata} Anak Luar Nikah

Dari pemaparan sebelumnya dapat diketahui bahwa terjadi tumpang tindih dan seperti terjadi simpang siur antara kedudukan anak hasil zina dan anak sah dalam perkawinan. Hukum legal di Indonesia termasuk HAM, UU No. 1 Tahun 1974, Putusan MK menyetujui tentang hubungan perdata antara anak luar nikah dan ayah biologis. Hubungan perdata masih menjadi sebuah dilema tersendiri, apakah sampai kepada nasab atau hanya sebatas hubungan perdata seperti nafkah, wasiat wajibah dan bukan termasuk warisan dan perwalian (nasab).

Sementara hukum Islam menghendaki hubungan perdata tidak sampai pada nasab. Termasuk pendidikan, belanja, dan nafkah adalah sebuah pemberian yang pantas dilakukan oleh siapapun. Sebuah hukum yang mewajibkan ayah biologis dan ibu biologis untuk bertanggungjawab terhadap anak yang dilahirkan adalah sebuh keniscayaan dan sudah seharusnya.

Sedikit perbedaan tentang sudut pandang terhadap anak hasil zina adalah sebuah pertimbangan menuju sebuah tujuan hukum dibentuk. Tujuan hukum Islam tidak terlepas dari tujuan hidup manusia itu sendiri, yaitu mengabdi kepada Allah. Hukum buat agama Islam hanya berfungsi mengatur kehidupan manusia, baik pribadi maupun dalam hubungan kemasyarakatan yang sesuai dengan kehendak Allah, untuk kebahagiaan hidup manusia di dunia dan akhirat. Dengan kata lain, hukum dalam agama Islam terlingkup dalam masalah ta'abbudi. ${ }^{13}$

Tujuan dari hukum sipil tidaklah demikian langsung hubungannya dengan Tuhan, karena yang ingin dicapai oleh hukum sipil hanyalah "kedamaian" dalam masyarakat dengan mengatur kepentingan-kepentingan antara manusia yang satu dengan manusia yang lain dalam kehidupan bermasyarakat. ${ }^{14}$

Hubungan perdata yang tidak dibatasi dikhawatirkan mengurangi kesadaran manusia tentang buruknya perbuatan zina. Terlebih hukuman bagi pezina tidak ada diterapkan di Indonesia ini, maka dampak negatif dari tindakan

${ }^{13}$ Busthanul Arifin, Pelembagaan Hukum Islam di Indonesia Akar Sejarah, Hambatan dan Prospeknya (Jakarta: Gema Insani Press, 1996), hlm. 45.

${ }^{14}$ Arifin, Pelembagaan Hukum Islam di Indonesia Akar Sejarah, Hambatan dan Prospeknya, hlm. 45. 
FITRAH Jurnal Kajian Ilmu-ilmu Keislaman

Vol. 04 No. 2 Desember 2018

buruk tersebut tidak terlihat lagi di dunia. Maka dikhawatirkan merusak jiwa dan pribadi manusia dalam beragama.

\section{Analisis Penulis terhadap putusan MK}

Isi pasal 43 ayat (2) UU No. 1 Tahun 1974: Anak yang dilahirkan di luar perkawinan hanya mempunyai hubungan perdata dengan ibunya dan keluarga ibunya. Hubungan perdata yang dimaksudkan adalah anak yang lahir di luar perkawinan bernasab dengan ibunya saja, dalam arti segala jenis hubungan keperdataan termasuk hal waris dan nafkah menjadi tanggungjawab ibu saja. Kemudian pasca putusan MK yang lahir akibat permohonan uji Machicha Muchtar selaku mantan istri sirri alm. Moerdiono kepada MK untuk melegalkan perkawinan di bawah tangan dan supaya anak hasil perkawinan sirri tersebut dapat dihubungkan kekeluargaannya kepada bapak si anak (Moerdiono) di mana berdampak pada anak sirri mendapatkan hak-haknya sebagaimana mestinya hak anak-anak sah lainnya.

Namun MK hanya mengabulkan uji materi pada 1 pasal saja yakni pasal 43 ayat 1 di mana sebelumnya anak hanya memiliki hubungan perdata dengan ibunya saja kemudian dapat memiliki hubungan perdata dengan ayah biologis dengan pembuktian teknologi atau alat bukti lainnya. Namun yang menjadi kegundahan penulis adalah bagaimana mungkin anak hasil pernikahan sirri dipersamakan kedudukannya dengan anak luar perkawinan. Setidaknya meskipun guna melindungi hukum pencatatan perkawinan, ada baiknya penggunaan kata di luar nikah tidak diperuntukkan bagi anak yang lahir akibat perkawinan di bawah tangan.

Mengenai kata "hubungan perdata" sudah seharusnya MK memberikan penafsirannya secara jelas dan pasti agar tidak terjadi perbenturan antara hukum Islam dengan keputusan MK. Islam tidak membenarkan anak hasil zina bernasab dengan lelaki yang merupakan ayahnya tanpa adanya perkawinan sebelumnya. Hukum Islam juga tidak membenarkan anak hasil zina berhak atas warisan ayah biologis. Sebenarnya putusan MK tentang hubungan perdata baik apabila jelas dan tidak kabur. Jika yang dimaksud hubungan perdata adalah sebatas nafkah (belanja hidup) serta bantuan pendidikan, dan wasiat wajibah maka sama sekali tidak bertentangan dengan hukum Islam. Hal ini disebabkan Hukum Islam juga mengajarkan untuk saling tolong menolong, menafkahi anak yatim, maka dengan demikian kedudukan anak yang lahir akibat lelaki yang menghamili 
wanita lebih lagi. Sudah menjadi selayaknya lelaki tersebut memberikan nafkah kepada anak tersebut serta memberikan harta peninggalan dengan wasiat wajibah.

Selanjutnya, penulis berpikir bahwa akan lebih baik apabila sebelum MK memutuskan uji materi pasal, MK terlebih dahulu bermusyawarah dengan Majelis Ulama Indonesia supaya tidak terjadi kekaburan hukum dan kesewenang-menangan. Sebab negara Indonesia juga mengakui Islam sebagai salah satu agama di Indonesia, maka sudah sepatutnya putusan tersebut tidak menyalahi kaidah Islam. Sebagai tambahan lagi, bagaimana mungkin anak yang lahir dari perkawinan di bawah tangan masuk ke dalam kategori anak di luar nikah bersama-sama dengan anak hasil zina.

\section{KESIMPULAN}

Pada dasarnya setiap anak yang lahir di dunia adalah suci terlepas dari latar belakang lahirnya anak. Karena yang melakukan perbuatan dosa zina adalah orang tuanya, maka seorang anak tidak sepantasnya mengemban dampak negatif yakni tidak pandang oleh hukum. Lahirnya putusan MK memberikan nuansa baru di mana seorang lelaki yang mengakibatkan lahirnya seorang bayi yang sebelumnya lepas dari tanggungjawab nafkah untuk kemudian anak diberikan hak keperdataan atas ayah biologis dengan pembuktian. Adapun pembuktian yang dimaksud adalah ilmu pengetahuan atau teknologi yang dapat menunjukkan bahwa ada hubungan darah antara anak dan ibu atau ayah biologis.

Kata "hubungan perdata " dalam putusan memberi masalah baru , apakah hubungan perdata sampai kepada nasab yang berimplikasi pada hak waris atau hanya sebatas hubungan perdata biasa demi menjamin keberlangsungan hidup dan masa depan anak. MK tidak memberikan penafisiran yang jelas sehingga ada pro dan kontra di antara setiap sudut pandang hukum.

Dalam putusan MK, anak hasil pernikahan yang tidak dicatatkan masuk pada kategori anak luar nikah. Sehingga hak-hak seorang anak harus juga daiperoleh dengan pembuktian teknologi yang menunjukkan bahwa terdapat hubungan biologis antara anak hasil nikah sirri dengan ayahnya. 
FITRAH Jurnal Kajian Ilmu-ilmu Keislaman

Vol. 04 No. 2 Desember 2018

\section{DAFTAR PUSTAKA}

Al-Iraqi, Butsainah As-Sayyid. Berkah Mengasuh Anak Yatim. (Solo: Kiswah, 2013).

Arifin, Busthanul. Pelembagaan Hukum Islam di Indonesia Akar Sejarah, Hambatan dan Prospeknya. Jakarta: Gema Insani Press, 1996.

Az-Zuhaili, Wahbah. Fiqih Islam Wa Adillatuhu, (Jakarta: Gema Insani, 2011).

Hamdan, Muhammad Faisal. Hukum Keluarga Islam dalam Perspektif HAM Universal (UDHR) dan HAM Islam (UIDHR). Medan: Pasca Sarjana UIN Sumatera Utara, 2015.

Hermawan, Sulhani. "Kedudukan Waris Anak di Luar Nikah" dalam Problematika Hukum Kewarisan Islam Kontemporer di Indonesia, diedit oleh Muchit A.Karim. Jakarta: Puslitbang Kehidupan Keagamaan Badan Litbang dan Diklat $\begin{array}{llll}\text { Kementerian } & \text { Agama } & 2012 .\end{array}$ http://simbi.kemenag.go.id/pustaka/images/materibuku/problematika\%2 0hukum\%20kewarisan\%20islam\%20kontemporer\%20di\%20indonesia2012.pdf.

Irfan, H. M. Nurul. Nasab \& status anak dalam hukum Islam. Jakarta: AMZAH, 2013.

Jahar, Asep Saepudin, dan dkk. Hukum Keluarga, Pidana, dan Bisnis. Jakarta: Kencana Prenadamedia Group, 2013.

Majelis Umum PBB/ United Nations Information Centre, Indonesia. "Universal Declaration of Human Right (UDHR) tentang HAM Internasional." Web. Blog, $10 \quad$ Desember 1948. https://www.ohchr.org/en/udhr/pages/Language.aspx?LangID=inz.

Nasution, Amin Husein. Hukum Kewarisan. Jakarta: Rajawali Pers, 2012.

Rusyd, Ibnu. Bidayatul Mujtahid. Jakarta: Pustaka Azzam, 2007. 